\title{
Manufacturing Industry Environment: The Effect of Incentive Structures on Group Performance
}

\author{
FAHMI RIZANI, ANTONIUS G. SONDAKH, SARWANI \\ Faculty of Economics and Business, Universitas Lambung Mangkurat, Banjarmasin 219, Indonesia \\ Email correspondence: rizanifahmi@yahoo.com, sondakh.anton@gmail.com, sarwanifekon123@gmail.com
}

\begin{abstract}
In the manufacturing industry environment, assembly lines and teams are applied to several industries such as Ford's automotive industry that implements assembly lines and Volvo which implements teams (Libby and Thorne, 2009). This study aims to examine the effect of incentive structures on group performance in a manufacturing environment. The incentive structures used in this study are individual incentives, group incentives, and mixed incentives, while the manufacturing environment used is the assembly line and team. This research is a laboratory experiment which involved 150 students as the subject sample for the study and it used factorial design $3 \times 2$ between subjects. The subject sample was assigned to a create building using bricks in accordance with the instructions. The results showed that the incentive structure influenced the group performance on the assembly line and team. It was found that in a team, group incentives motivate group members to interact, share information, and work together to produce more wonderful results, group incentives produce higher group performance than individual and mixed incentives. In regard to assembly lines, individual incentives result in higher group performance than the group and mixed incentives, since individual incentives tend to motivate individuals to work for better outputs. The result may not be generalizable because of the limitations both of experimental methods and the instruments we develop. Therefore further research may enlarge the use of experimental subjects by involving students with higher levels of education, or practitioners of production employees as experimental subjects, and may also consider the issue of other incentive structures in the manufacturing environment.
\end{abstract}

Key words: Assembly line, Group performance, Incentive structure, Manufacturing environment, and Team.

\section{Lingkungan Industri Manufaktur: Pengaruh Struktur Insentif Pada Kinerja Kelompok}

\begin{abstract}
Abstrak
Dalam lingkungan industri manufaktur, lini perakitan dan tim diterapkan beberapa industri seperti industri otomotif Ford yang menerapkan lini perakitan dan Volvo yang menerapkan tim (Libby dan Thorne, 2009). Penelitian ini bertujuan untuk menguji pengaruh struktur insentif terhadap kinerja kelompok di lingkungan manufaktur. Struktur insentif yang digunakan dalam penelitian ini adalah insentif individu, insentif kelompok, dan insentif campuran, sedangkan lingkungan manufaktur yang digunakan adalah lini perakitan dan tim. Penelitian ini merupakan eksperimen laboratorium yang melibatkan 150 mahasiswa sebagai subyek dan menggunakan disain faktorial 3 x 2 antar subyek. Subyek ditugaskan untuk membuat bangunan dengan menggunakan brick sesuai dengan petunjuk. Hasil penelitian menunjukkan bahwa struktur insentif berpengaruh terhadap kinerja kelompok pada lini perakitan dan tim. Bagi tim, karena insentif kelompok memotivasi anggota kelompok untuk berinteraksi, berbagi informasi, dan bekerja sama untuk menghasilkan lebih banyak hasil, maka insentif kelompok menghasilkan kinerja kelompok yang lebih tinggi daripada insentif individu dan campuran. Di lini perakitan, insentif individu menghasilkan kinerja kelompok yang lebih tinggi daripada insentif kelompok dan campuran karena dorongan individu memotivasi usaha individu untuk menghasilkan lebih banyak output. Hasil ini mungkin tidak dapat digeneralisasikan karena keterbatasan metode eksperimen dan instrumen yang kami kembangkan. Oleh karena itu penelitian selanjutnya dapat memperbesar penggunaan subyek eksperimental dengan melibatkan siswa yang lebih tinggi tingkat pendidikannya, atau praktisi dari karyawan produksi sebagai subjek eksperimen, dan mungkin juga mempertimbangkan isu struktur insentif lainnya di lingkungan manufaktur.
\end{abstract}

Kata kunci: Kinerja Grup, Lingkungan Manufaktur, Lini Perakitan, Struktur Insentif, Tim. 
Jurnal Bisnis \& Manajemen, 2018, Vol. XIX, No. 1, 3-12

Available at: $h$ ttp://journal.feb.unpad.ac.id/index.php/jbm

\section{INTRODUCTION}

Manufacture is the process of transforming materials or raw materials into the components of a product or finished product. The manufacturing process involves a combination of machines, equipment, energy, and manpower (Groover, 2010: 3). According to Baroto (2002: 13), as a system, manufacture is a collection of the subsystem which consists of design subsystem, quality assurance subsystem, marketing subsystem, and production subsystem. These entire manufacturing subsystems are interrelated and mutually supportive. Production subsystem is one of the manufacturing subsystems which must be considered because the level of efficiency and effectiveness of the manufacturing process is determined in the production process. The production process is the main activity in the manufacturing company.

In connection with the production process, Meer R \& Gudim (1996) in Libby and Thorne (2009) stated that assembly lines and teams are the form of production environment which are commonly observed. In addition, assembly lines and teams are also applied in several industries such as Ford automotive industry which implements the assembly lines and Volvo which implements the teams (Libby and Thorne, 2009). The assembly line is a manufacturing process where the parts and components of the finished product are assembled one by one into one entity in a sequential manner by the workers to create the finished product (Thomopoulos, 2014: 7). The assembly line concept renders the production process to be divided into each section or modular, with each module or part responsible for the completion of the certain task with the specified input and output. Meanwhile, team production environment is a production environment in which each member works as a team to generate the final output. Each employee in the assembly line workstation has their own work and responsibilities. Employees perform similar job repeatedly (a monotonous job). Unlike the assembly lines, team production environment provides flexibility for the employees. Employees working in teams can interact, share information, and work with other employees.

In the production process, employee's performance may be assessed as a group performance because
JURNAL BISNIS \& MANAJEMEN

ISSN 1412 - 3681

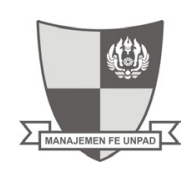

most employees in the manufacturing environment work in groups (small groups or even large groups). To motivate the performance of the employee in the manufacturing environment, it is necessary to design an appropriate incentive structure. Kovach (1987) claimed that incentives are included in the ten points that motivate the work of the employees. Wiley (1997) stated that incentive is the best extrinsic rewards, therefore the selection of appropriate incentive structures is necessary for the improvement of group performance.

Various literature have considered appropriate incentive designs in motivating groups and increasing group outputs in different production environments, including the assembly lines and teams (Boudreau et al., 2003). Young, et al. (1993) examined the effect of group incentives on group performance in cooperative environments (team production environments) and noncooperative (assembly line production environments). Young, et al. (1993) argued that groups which are allowed to cooperate will excel groups that are not allowed to cooperate when group incentives are given. However, the research results of Young, et al. (1993) discovered that noncooperative groups produce more output than cooperative groups. Furthermore, Libby and Thorne (2009) examined the effect of incentive structures of individuals, groups, and mixed towards group performance in assembly lines and teams.

The research of Libby and Thorne (2009) is a development of Young, et al. (1993) research. The research result of Libby and Thorne (2009) proved that for the team production environments, group incentives produce higher group performance than the individual or mixed incentives. The research result of Libby and Thorne (2009) also discovered that in the assembly line environment conditions, individual incentives did not generate higher group performance than group incentives and mixed incentives. The research result of Libby and Thorne (2009) differed from the research result conducted by Young et al. (1993). The research result of Young et al. (1993) proved that group incentives resulted in higher performance in noncooperative group conditions (assembly line environments in the research of Libby and Thorne), whereas the research result of Libby and Thorne (2009) proved that group incentives 
JURNAL BISNIS \& MANAJEMEN

ISSN 1412 - 3681

resulted in higher performance in team environment (cooperative group in the research of Young et al.).

This research aimed to examine whether incentive structures which consist of individual incentives, group incentives, and mixed incentives will affect the group performance in the manufacturing environment (assembly lines and teams). This research would like to prove empirically that, in a team production environment, group incentives generate higher group performance than the individual incentives and mixed incentives; whereas, in the assembly line production environments, individual incentives generate higher group performance than the group incentives and mixed incentives. The results of this research will additionally enrich the literature, particularly in the field of management accounting, it is also expected to be a consideration for the management in designing the incentive structure of the employees; production employees in particular. Providing appropriate incentives in the form of production environment used by the company is expected to maximize the performance of the employees.

\section{LITERATURE REVIEW}

The goal interdependence theory by Morton Deutsch discussed the existence of goal interdependence among individuals involved in certain situations. According to Deutsch (2006: 24), there are two basic types of interdependence, namely positive interdependence, and negative interdependence. Positive interdependence will result in interactions which mutually support the goal achievement, whereas negative interdependence will result in interactions which inhibits the goal achievement. This research used a positive interdependence situation as the theoretical basis. As it has been described earlier, positive interdependence will result in interactions which mutually support the individuals and one form of such interaction is cooperation among the individuals.

Deutsch (1990) in Libby and Thorne (2009) predicted that group members tend to interact and cooperate to improve their performance to achieve group goals rather than individual goals. According to the theory, in a group, group members will be pleased to cooperate which includes mutual assistance
Jurnal Bisnis \& Manajemen, 2018, Vol. XIX, No. 1, 3-12 Available at: http://journal.feb.unpad.ac.id/index.php/jbm

and coordination to achieve common goals which are the group goals. Comprehension regarding the goal interdependence theory is necessary for a manufacturing company, considering that employees in manufacturing companies, specifically in the production environment where most of the employees work in groups. Employees work in small groups as well as large groups to produce output or products.

Merchant (1982) expressed that in the context of accounting, goals or targets are often associated with incentive contracts to support the resultoriented management control system. For instance, financial incentive contracts motivate performance by inserting compensation variable that depends on the relative performance towards the predetermined targets. Based on the goal interdependence theory, we predict that group performance will be higher for the assembly lines with individual incentives (an incentive contract where the assigned target motivates individual performance) rather than with group incentives because individual incentives inhibit the group members from interaction and cooperation. On the other hand, in a team production environment, benefits may be actualized through cooperation and interaction among group members. We predict that group incentive structures (incentive contracts where the assigned target motivates group performance) should result in higher group performance than individual incentive structures for the team production environment.

Hinrichs and Tenkasi (2007) claimed that group incentives can be the best motivating effort in modern manufactures that relies on the production teams. Young et al (1993) asserted that groups which are allowed to interact will perform better than groups which are not allowed to interact when group incentives are given. Even though, it is not supported by the results of their research. Libby and Thorne (2009) referred to the goal interdependence theory and predicted that when group members can provide useful information about how to perform tasks well (team production environment), group incentives will motivate group members to interact, share information and learn from other members.

Libby and Thorne (2009) suggested that group 
Jurnal Bisnis \& Manajemen, 2018, Vol. XIX, No. 1, 3-12

Available at: http://journal.feb.unpad.ac.id/index.php/jbm

incentives will result in higher group performance than the individual and mixed incentives. The statement is supported by their research results which indicated that group incentives result in higher group performance than individual incentives and mixed incentives on environments which are allowed to interact. They also examined the effects of mixed incentives (a combination of individual incentives and group incentives) towards group performance in the team production environment and assembly lines. Mixed incentives are also commonly used in practice (Hwang, Erkens, \& Evans III, 2007). Based on theories and previous studies, therefore the first hypothesis may be formulated as follows:

H1: For teams, group incentives will result in higher group performance than individual incentives and mixed incentives

Hemmer (1995) in Libby and Thorne (2009) stated that individual incentive is the best motivating effort for assembly lines. Young et al. (1993) claimed that when noncooperative groups attempted with greater efforts to generate output, cooperative groups interact to develop new strategies. Young et al. (1993) argued that cooperative groups will excel noncooperative groups when group incentives are given. However, the research result of Young et al. (1993) proved that noncooperative groups produce more output than the cooperative groups.

According to the goal interdependence theory, Libby and Thorne (2009) predicted that group performance would be higher for assembly lines with individual incentives than group incentives because individual incentives inhibit group members from interaction and cooperation. Individual incentives will be more suitable than group incentives because individual incentives encourage group members to focus on their individual efforts in producing more output, rather than on the interaction and cooperation with other group members (Libby \& Thorne, 2009). Based on theories and previous studies, therefore the second hypothesis may be formulated as follows:

H2: For assembly lines, individual incentives will result in higher group performance than group incentives and mixed incentives
JURNAL BISNIS \& MANAJEMEN

ISSN 1412 - 3681

\section{RESEARCH METHODS}

According to the type of research based on the purpose of its generalization, this research is the theory application research (RAT). The theory application research is a research in which researchers will generalize the theory, not the results of research, towards different situations and conditions (Nahartyo, 2013: 60). RAT is more concerned with internal validity than external validity (Nahartyo, 2013: 61). The experimental method has several advantages in the internal validity. Therefore, this research used experimental methods. Hartono (2015: 119-120) suggested that experiment is a study which involves the researchers in manipulating the variables, and subsequently observe the effect towards the subject or participants studied. In this case, the variables treated, or in other words manipulated, are independent variables and dependent variable in which its effect is observed.

This research was conducted by using laboratory experimental design with $3 \times 2$ factorial design. A factorial design is an experimental design used to examine the effect of two or more independent variables simultaneously (Nahartyo \& Utami, 2016: 103). The manipulated independent variables are the three incentive structures namely individual incentives, group incentives, and mixed incentives. While the dependent variable is group performance.

\section{Research Subject and Experimental Design}

This research involved a total of 150 students (72 students of Accounting Undergraduate Program and 78 students of Accounting Diploma) which is divided into 50 groups. $3 \times 2$ between-subject factorial design and the number of group distributions can be seen in table 1 below:

Table 1. 3x2 between-subject experimental design

\begin{tabular}{cccc}
\hline \multirow{2}{*}{ Manipulated Independen Variable } & \multicolumn{2}{c}{ Production Environment } \\
\cline { 2 - 4 } & Individual & $\mathrm{Assembly}$ Line & Team \\
\hline Group & $\mathrm{N}=10$ & $\mathrm{~B}$ \\
Incentive & $\mathrm{C}$ & $\mathrm{N}=8$ \\
Structure & $\mathrm{N}=8$ & $\mathrm{D}$ \\
& Mixed & $\mathrm{E}$ & $\mathrm{N}=8$ \\
& & $\mathrm{~N}=8$ & $\mathrm{~F}$ \\
& & & $\mathrm{~N}=8$ \\
\hline
\end{tabular}




\section{JURNAL BISNIS \& MANAJEMEN}

ISSN 1412 - 3681

Under condition $A$, participants are located in an assembly line environment condition and stimulated with individual incentives. Under condition B, participants are located in a team environment condition and stimulated with individual incentives. Under condition C, participants are located in an assembly line environment and stimulated with group incentives. Under condition D, participants are located in a team environment and stimulated with group incentives. Under condition $E$, participants are located in an assembly line environment and stimulated with mixed incentives. Under condition $\mathrm{F}$, participants are located in a team environment and stimulated with mixed incentives.

\section{Experimental Procedure}

The number of groups involved in the experiment was 50 groups for 6 manipulation conditions. Experiment implementation required approximately 30 minutes. Participants were divided into groups of
Jurnal Bisnis \& Manajemen, 2018, Vol. XIX, No. 1, 3-12 Available at: http://journal.feb.unpad.ac.id/index.php/jbm

3 and placed in one random condition. Participants received experimental materials in the form of bricks, instruction sheets, and assignment sheets. The instruction sheet consists of three instructions (see figure 1), namely: 1. Picture of the building; 2 . Picture of the building's components; and 3. Instructions for the arrangement.

The assignment sheet contains the descriptions of rewards to be received, questions that must be answered by the participants and the rules that must be followed by the participants. Participants will receive two assignment sheets, assignment sheet of session 1 and assignment sheet of session 2. The assignment sheet should be understood and answered by the participants at the beginning of each session. The following tables are the reward formula in the form of a table which is obtained by the respondents in sessions 1 and 2, and also the rules of the game enacted.
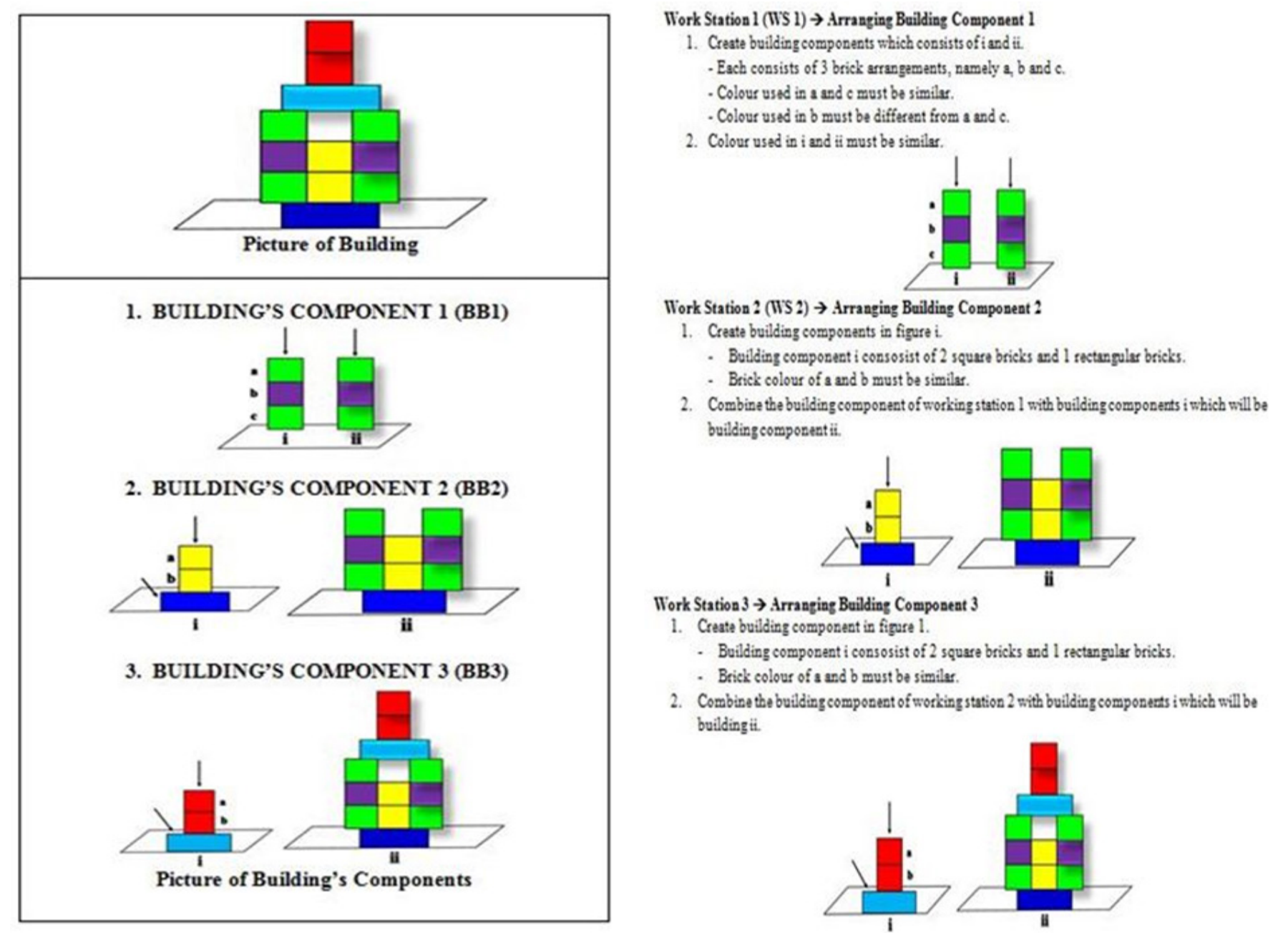

Figure 1. Instruction Sheet 
Jurnal Bisnis \& Manajemen, 2018, Vol. XIX, No. 1, 3-12

Available at: http://journal.feb.unpad.ac.id/index.php/jbm

Tabel 2. Rewards Formula of Session 1

\begin{tabular}{c} 
In General \\
$\mathrm{I}=\mathrm{i} \times \mathrm{H}$ \\
Individual Incentives \\
$\mathrm{I}=\mathrm{ii} \times \mathrm{Hi}$ \\
Group Incentives \\
$\mathrm{I}=\mathrm{ik} \times \mathrm{Hk}$ \\
Mixed Incentives \\
$\mathrm{I}=(\mathrm{ii} \times \mathrm{Hi})+(\mathrm{ik} \times \mathrm{Hk})$ \\
\hline
\end{tabular}

Description of table 2:

$\mathrm{I}=$ Rewards

li $=$ Rewards per unit of building components

Ik = Rewards per unit of the building

$\mathrm{Hi}=$ The number of building components produced by individuals

$\mathrm{Hk}$ = The amount of building produced by groups

Tabel 3. Rewards Formula of Session 2

If the building components and te building generated are more than the assigned target (Result $>$ Target)

Indivual incentives

$\mathrm{I}=\mathrm{Gt}+(\mathrm{ii} \times(\mathrm{Hi}-\mathrm{Ti}))$

Group incentives

$\mathrm{I}=\mathrm{Gt}+(\mathrm{ik} \times(\mathrm{Hk}-\mathrm{Tk}))$

Mixed incentives

$\mathrm{I}=\mathrm{Gt}+(\mathrm{ii} \times(\mathrm{Hi}-\mathrm{Ti}))+(\mathrm{ik} \times(\mathrm{Hk}-\mathrm{Tk}))$

If the building components and the building generated are less than the assigned target (Result < Target)

$\mathrm{I}=\mathrm{Gt}$

Description of table 3:

$1=$ Rewards

Gt = Fixed Salary

ii = Rewards per unit of building components

ik = Rewards per unit of building

$\mathrm{Hi}=$ The number of building components produced by each participant

$\mathrm{Hk}=$ The number of building produced by groups

$\mathrm{Ti}=$ The number of building components target assigned

Tk = The number of building target assigned
JURNAL BISNIS \& MANAJEMEN

ISSN 1412 - 3681

Tabel 4. Rules in the Assignment Sheets

\begin{tabular}{ll}
\hline Team Production Environment & $\begin{array}{l}\text { Assembly Line Production } \\
\text { Environment }\end{array}$ \\
\hline $\begin{array}{l}\text { 1. Allowed to discuss with other } \\
\text { members }\end{array}$ & $\begin{array}{l}\text { 1. Prohibiited to discuss with other } \\
\text { group member }\end{array}$ \\
2. Allowed to help other members & $\begin{array}{l}\text { 2. Prohibited to help other group } \\
\text { members }\end{array}$ \\
3. Allowed to cooperate with other & $\begin{array}{l}\text { 3. Prohibited to cooperate with } \\
\text { members }\end{array}$ \\
\hline
\end{tabular}

Experiments were carried out in two sessions with similar tasks. The task of the participant is to establish a good quality building by using bricks within 2.5 minutes. Before the first session began, the participants were guided to do their tasks. This was done to provide a complete understanding related to the task and process of experimental implementation towards the participants. The first session was intended to determine the number of buildings which can be produced by the participants. The number of buildings produced by participants in the first session will be a consideration of targeting in the second session.

In the second session, participants were offered a new assignment sheet which differs from the assignment sheet of the first session. Meanwhile, the instruction sheet used in this session is similar to the one used in the first session. In this session, participants will receive information about the building target they need to produce. In the end, the participants will receive questionnaires that must be filled. The questionnaire contained demographic data of experimental subjects, manipulation checks, and questions related to the research.

\section{Operational Definition of Variables}

Dependent Variable. The dependent variable in this research is group performance. In this research, group performance is measured using the output generated by the group. The output is a good quality building produced by the group.

Independent Variable. The independent variable in this research is the incentive structure. The incentive structure consisted of individual incentives, group incentives, and mixed incentives.

Individual Incentives. The individual incentive is an incentive given based on the output produced by 


\section{JURNAL BISNIS \& MANAJEMEN}

ISSN 1412 - 3681

each individual. The output used in the calculation of individual incentives is a part of good quality building produced by each workstation.

Group Incentives. Group incentive is an incentive given based on the output produced by each group. The output used in the group incentive structure is a good quality building produced by the group.

Mixed Incentives. The mixed incentive is a unification of individual incentives and group incentives. Mixed incentives are calculated based on the amount of output produced by each workstation (components of good quality building) and groups (good quality buildings).

\section{Data Analysis Technique}

Data analysis technique used in this research is an analysis of variance (ANOVA). The dependent variable is group performance, which is a metric scale and the independent variable is incentive structure which is a non-metric or categorical scale. By using ANOVA as an analytical tool, accordingly, the effect of incentive structures in the form of individual incentives, group incentives, and mixed incentives towards group performance may be observed.

\section{RESULT AND DISCUSSION}

\section{The Result of Manipulation Checks}

Manipulation checks are performed to gain assurance that the subject has received manipulation that corresponds to the one designed by the researcher (Nahartyo \& Utami, 2016: 137). Manipulations of incentive structures (individuals, groups, and mixed) are carried out by using the incentive formula which is previously mentioned. To examined whether the subject has understood the incentive formula given, the researcher examined the subject by asking questions regarding the incentive structure which must be answered by the participants.

To check whether participants have violated the rules of interaction among group members which are the treatment of the team production environment and assembly line production environment, the researcher asked three questions towards the subject. The questions are: (1) Did you discussed the work with other members of the group during the
Jurnal Bisnis \& Manajemen, 2018, Vol. XIX, No. 1, 3-12 Available at: http://journal.feb.unpad.ac.id/index.php/jbm process? (2) Did you move from your workstation to help other members with difficulties in the group? (3) Did you learn to do the job assigned by looking at other members of the group? From the question, answers of the subjects are then analyzed. Analyzing the subject's answers was conducted by adjusting the answers to the subject's production environmental conditions in the experiment. From the results of manipulation checks conducted, the entire respondents of 150 people have answered the manipulation question correctly.

\section{Descriptive Statistics Analysis}

Teble 5. Descriptive Statistics of Group Performance

\begin{tabular}{lcc}
\hline Incentive Structure & $\begin{array}{c}\text { Team Production } \\
\text { Environment }\end{array}$ & $\begin{array}{c}\text { Assembly Line } \\
\text { Production } \\
\text { Environment }\end{array}$ \\
\hline Individual & 8 & 10 \\
$\mathrm{~N}$ & 11,75 & 13,70 \\
Mea & 10 & 12 \\
Minimum & 14 & 16 \\
Maximum & & 8 \\
Group Incentives & 8 & 11,88 \\
$\mathrm{~N}$ & 14,00 & 9 \\
Mea & 11 & 14 \\
Minimum & 18 & \\
Maximum & & 8 \\
Mixed Incentives & 8 & 11,75 \\
$\mathrm{~N}$ & 12,00 & 9 \\
Mea & 10 & 13 \\
Minimum & 15 & \\
Maximum & & \\
\hline Source: Data Processed (2017) & &
\end{tabular}

In the team production environment, the average value of group performance with the individual incentive structure is 11.75 in the team production environment and $\mathbf{1 3 . 7 0}$ in the assembly line production environment. The average value of group with group incentive structure is 14.00 in the team production environment and 11.88 in the assembly line production environment. With the mixed incentive structure, the average value of group performance is 12.00 in the team production environment and 11.75 in the assembly line production environment. The lowest minimum value is 9 (the condition of group incentives and mixed incentives on the assembly line), which means that the minimum amount of buildings produced by the group is 9 buildings. While the highest maximum value is 18 (the conditions of group incentives on the team production environment), 
Jurnal Bisnis \& Manajemen, 2018, Vol. XIX, No. 1, 3-12

Available at: http://journal.feb.unpad.ac.id/index.php/jbm

which means that the maximum amount of buildings produced by the group is 18 buildings.

\section{The Result of Hypothesis Tesis}

Table 6 provided the results of one-way ANOVA analysis of group performance variables in the two production environments. Table 6 indicated a significance value of 0.039 in the team production environment and a significance value of 0.020 in the assembly line production environment. The value is less than $0.05(p<0.05)$. Therefore, it can be concluded that the incentive structure effect towards the group performance in the team and assembly line production environment.

Table 6. One-Way ANOVA Test Results

\begin{tabular}{lllll}
\hline \multicolumn{5}{c}{ Dependent Variable: Group Performance } \\
\hline $\begin{array}{l}\text { Production } \\
\text { Environment }\end{array}$ & Independent Variable & $\mathrm{F}$ & Sig. & Description \\
Team & Incentive Structure & 3,785 & 0,039 & $\mathrm{H} 1$ accepted \\
Assembly Line & Incentive Structure & 3,641 & 0,020 & $\mathrm{H}$ 2 accepted \\
\hline Source: Data Processed (2017) & & &
\end{tabular}

Figure 2 is presented to answer the questions related to the research: (1) Does the group incentive structure produce higher group performance than the individual incentives and mixed incentives in the team production environment? and (2) Does the individual incentive structure produce higher group performance than the group incentives and mixed incentives in the assembly line production environment? The calculation of the average value of group performance in the team production environment indicated that group incentive stimulation may result in higher group performance than the individual incentives and mixed incentives. This is also proved by the average value of group performance with group incentives of 14.00 which is higher than group performance with individual and mixed incentives. The average value of group performance with individual incentives is $\mathbf{1 1 . 7 5}$ whereas the average value of group performance with mixed incentives is 12.00 . Figure 2 also supported that group incentive structures produce higher group performance in the team production environment. It can be concluded that the results of this test supported the first hypothesis, which stated that in a team production environment, group incentives will result in higher group performance than the individual incentives and mixed incentives.
The calculation of the average value of group performance in the assembly line production environment indicated that individual incentive stimulation may result in higher group performance than the group incentives and mixed incentives. This is also proved by the average value of group performance with the individual incentive of 13.70 which is higher than the group performance with individual and mixed incentives. The average value of group performance with group incentives is 11.88 whereas the average value of group performance with mixed incentives is 11.75 . It can be concluded that the results of this test supported the second hypothesis, which stated that in the assembly line production environment, individual incentives will result in higher group performance than the group incentives and mixed incentives.

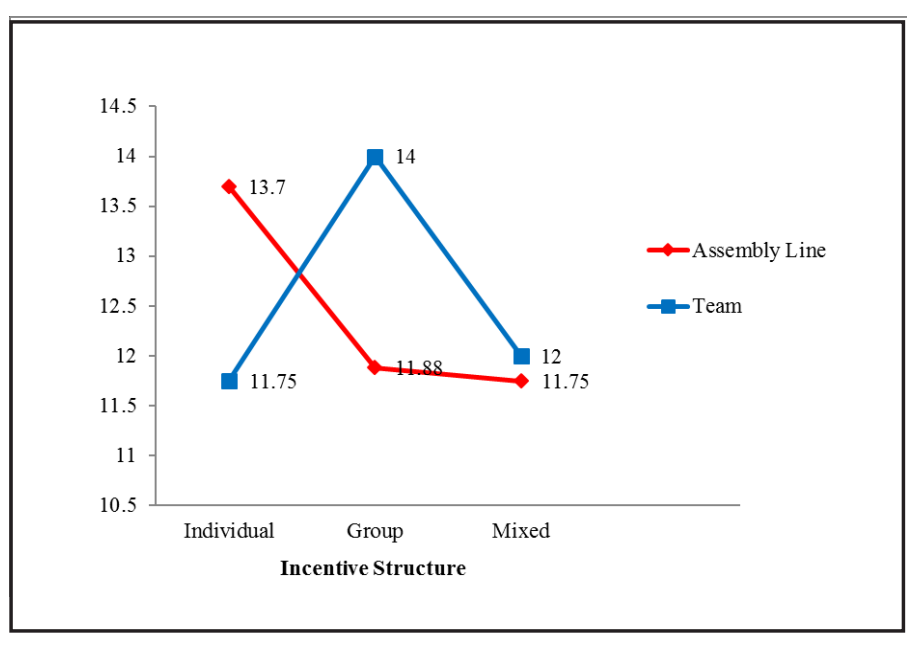

Figure 2. The Average Value of Group Performance

The results of this research are consistent, unidirectional, and supportive with the perspective of goal interdependence theory, which stated that in a team production environment (the presence of interaction and cooperation among group members), group incentives (an incentive contract in which the specified targets motivate group performance) generated higher group performance than the individual and mixed incentives. Meanwhile, in an assembly line production environment (the presence of interactions are prohibited), individual incentives (an incentive contract in which the specified targets motivate individual performance) generated higher group performance than the group incentives and mixed incentives. 
JURNAL BISNIS \& MANAJEMEN

ISSN 1412 - 3681

In a team production environment, group incentives may motivate group members to interact, share information, cooperate, and learn from other group members. Young et al. (1993) also stated that group incentives will result in higher performance in cooperative groups. The results of this research were also consistent with the research results of Libby and Thorne (2009) which also indicated that, in the team production environment, group incentives resulted in higher group performance than the individual incentives and mixed incentives. Meanwhile, individual incentives generated higher performance in assembly line production environments because individual incentives motivate group members to focus on producing more output.

\section{CONCLUSION}

The results of this research were in accordance with the goal interdependence theory, which stated that group members tend to interact and cooperate to improve its performance to achieve the group goals rather than individual goals. According to the goal interdependence theory, in a team production environment when group members cooperate, group incentives (incentives based on group targets or goals) result in higher group performance than the individual incentives and mixed incentives. This is because group incentives can motivate group members to interact, share information, cooperate, and learn from other group members. In assembly line production environments when group members are prohibited to interact, individual incentives (incentives based on individual targets or goals) results in higher group performance than the group incentives and mixed incentives. Individual incentives generated higher group performance in assembly line production environments because individual incentives motivate individual efforts to focus on producing more output.

This research used experimental methods which own several limitations, namely low external validity, therefore, the results may not be generalized. In addition, the materials in this research were designed with limited information from previous research, but based on pilot tests conducted prior to the main experiments, the researchers assumed that the materials used in the main experiments
Jurnal Bisnis \& Manajemen, 2018, Vol. XIX, No. 1, 3-12 Available at: http://journal.feb.unpad.ac.id/index.php/jbm were suitable with the research objectives and this could support the implementation of the experiments. Another limitation laid in the pilot test which is only performed on several groups with six different conditions, therefore the limited amount of groups affected the statistical test results of the pilot test. Based on the limitations of the research, the suggestions which may be considered for the further research is to enlarge the use of experimental subjects by involving students with higher levels of education or by involving practitioners (in this case the production employee as the subject of the experiment). In addition, further research may also consider recent issues related to incentive structures in the manufacturing environment. Therefore the further research should be enlarged.

\section{Acknowledgment}

We take this opportunity to thank the Dean Faculty of Economics and Business (Dr. Riza) of Universitas Lambung Mangkurat for the support provided during the process of writing to the publication of this manuscript. We also thank all colleagues at the department of the faculty in general for their motivation. Our prayer is that God rewards abundantly!

\section{REFERENCES}

Baroto, T. (2002). Perencanaan dan Pengendalian Produksi. Jakarta: Ghalia Indonesia.

Boudreau, J., Hopp, W., McClain, J., \& Thomas, I. (2003). On the Interface Between Operations and Human Resources Management. CAHRS Working Paper Series, 02-22.

Deutsch, M. (2006). Cooperation and Competition. Dalam M. Deutsch, P. T. Coleman, \& E. C. Marcus, The Handbook of Confilct Resolution: Theory and Practice (Second ed., hal. 23-42). San Francisco: Jossey-Bass.

Groover, M. P. (2010). Fundamentals of Modern Manufacturing: Materials, Processes, and System. Hoboken: John Wiley \& Sons, Inc.

Hartono, J. (2015). Metodologi Penelitian Bisnis: Salah Kaprah dan Pengalaman-pengalaman 
Jurnal Bisnis \& Manajemen, 2018, Vol. XIX, No. 1, 3-12

Available at: http://journal.feb.unpad.ac.id/index.php/jbm

(Keenam ed.). Yogyakarta: BPFE.

Hinrichs, G., and R. Tenkasi. (2007). Enactment, sensemaking and social agreement: An interpretive model of implementing high performance work systems. Research in Organization Change and Development. Greenwich, CT: JAI Press.

Hwang, Y., Erkens, D., \& Evans III, J. (2007). Knowledge Sharing and Incentives Design in Production Environments: Theory and Evidence. 1-39.

Kovach, K. A. (1987). What Motivated Employees? Workers and Supervisors Give Different Answers. 58-65.

Libby, T., \& Thorne, L. (2009). The Influence of Incentive Structure on Group Performance in Assembly Lines and Teams. Behavioral Research in Accounting, 21, 57-72.

Merchant, K. A. (1982). The control function of management. Sloan Management Review 23 4_: 43-56.
JURNAL BISNIS \& MANAJEMEN

ISSN 1412 - 3681

Nahartyo, E. (2013). Desain dan Implementasi Riset Eksperimen (Kedua ed.). Yogyakarta: UPP STIM YKPN.

Nahartyo, E., \& Utami, I. (2016). Panduan Praktis Riset Eksperimen. Jakarta: PT. Indeks.

Thomopoulos, N. (2014). Assembly Line Planning and Control. London: Springer International Publishing Switzerland.

Wiley, C. (1997). What Motivates Employess According to Over 40 Years of Motivation Surveys. International Journal of Manpower, 18(3), 263-280.

Young, S., Fisher, J., \& Lindquist, T. (1993). The Effect of Intergroup Competition and Intragroup Cooperation on Slack and Output in a Manufacturing Setting. The Accounting Review, 68(3), 466-481. 